\title{
INTEGRATING AUGMENTED REALITY (AR) IN EFL CLASS FOR TEACHING VOCABULARY
}

\author{
Irma Savitri Sadikin ${ }^{1}$, Erista Martyani ${ }^{2}$ \\ ${ }^{1}$ Universitas Esa Unggul \\ ${ }^{2}$ SDN Kertamulya Padalarang \\ ${ }^{1}$ irma.savitri@esaunggul.ac.id, ${ }^{2}$ eristask1@gmail.com
}

\begin{abstract}
In the industrial era 4.0, the use of technology in the learning process is an important element. Teachers need to be more technologically in their teaching process since the use of technology has become a lifestyle. Augmented Reality (AR) is an interactive experience of a real-world environment which is considered effective as good medium in learning especially in English vocabulary. This article aims to explore the use of AR for young learners by comparing it with conventional paper flashcards. This method used quantitative research or more specifically quasi-experimental design at the second grade of Primary school in Padalarang. The data of the research was obtained from pre-test and post-test and it was analyzed by using SPSS 22 for windows. The results showed that both AR and conventional flashcard could significantly improve young learners' vocabulary. However, the mean score of posttest in experimental class was 74.83 and 62.5 for control class. The data analysis revealed that the null hypothesis was rejected. In other word, the posttest score of experimental class was higher than control class. In summary, learning English vocabulary through augmented reality (AR) could improve students' vocabulary mastery. It made young learners more engaged and excited to learn English vocabulary.
\end{abstract}

Keywords: Augmented Reality, Teaching Vocabulary, Young Learners

\section{INTRODUCTION}

In learning a foreign language, vocabulary is an element that links the four skills of language. As the important component to master language one should have sufficient vocabulary in order to communicate effectively. It is in line with Marianne (2001) in Sadikin (2011) who states that learning language cannot be separated from learning vocabulary. Vocabulary supports the speaker to express their opinions, ideas, and feelings in communication. Brown (2001:11) adds that there are two types of vocabulary. They are active and passive. Active vocabulary (productive) is used in oral or written and is made up of words that come up in person's mind immediately when he or she has to produce a spoken or written sentence. On the other hand, passive vocabulary (receptive) is not used by a person.

People understand it when it is heard or read. More specifically, we use vocabulary to refer to the kind of words that students must know to read increasingly demanding text with comprehension (Hiebert, 2005) as cited in Nurdiansyah, Asyid, \& Parmawati (2019). . Some barriers faced when young learners learned with the function of vocabulary word. The first challenge is from the misleading conception of teaching English for young learners. This is supported by Paul (2003) and Pinter (2006). They claim that the eagerness of young learners can be bettered down if they are frequently overwhelmed by the developmentally inappropriate experiences. Students' interest might be regarded as the most essential elements to be taken into account for achieving a more successful teaching and learning (Apsari, 2012). Therefore, media 
in the learning process very importance to help students become effective and interesting in learning process. Media in the learning process very importance to help students become effective and interesting in learning process.

Much has been written about describing the characteristics and learning style of the Generation $\mathrm{Z}$ to show who they are and how they differ from the former generations. Knowing them well affects the students 'ways of learning. According to Barcelon (2010), He classifies generations $\mathrm{Y}$ and $\mathrm{Z}$ have both been growing to maturity in the age of the computer and internet. Looking at the age classification proposed by Lancaster and Stillman (2002) it can be predicted that the oldest members of Generation $Z$ are this year's elementary school students. When the concept of generation is directed to primary school level, the group of the generation $\mathrm{Z}$ belongs to young learners'category. They are identified as tech savvy, social, multitasking, and speedy.

Augmented Reality (AR) is an interactive experience of a real-world environment whereby the objects that reside in the real-world are "augmented" by computer generated perceptual information, sometimes across multiple sensory modalities, including visual, auditory, haptic, somatosensory, and olfactory. Mobile Augmented Reality (MAR) based on Doswell et al (2006) is a term used when equipment through which we achieve AR is small in size and typically easy to carry e.g. a smartphone or a tablet. In using AR flashcards, the learners enable to interact with the virtual objects as if the objects are real seen in front of them. They can find some specific information related to the object itself using tablet or smart phone. The 3D object comes alive if they take a photo of the virtual object. For example, if an AR flashcard is a whale, a virtual whale will appear on the mobile device and the learners can click on some information available, such as origin, diet, size, organ, etc. if the learners touch its body from the mobile screen, the virtual whale can react and move 360 degrees, therefore, the learners are able to see it in real-life environment.

Some studies reported that AR enables to increase student-centered learning. Vate-U-Lan (2012) recognizes that the regarded AR application enabled the tailoring of functionality to student's learning capabilities. Similarly, Kama-rainen et al (2013) report that "these technologies provide ways of individualizing instruction in a group setting and that the technology supported independence which freed the teacher to act as a facilitator". Furthermore, Liu et al. (2009) report that AR improves the ability to explore and absorb new knowledge and solve problems. It indicates that AR can support student-centered learning environments as students are enabled to explore knowledge and solve problems autonomously. Some studies found that AR can support the learners with new possibilities to individualize their lessons according to students' capabilities and by enabling students to learn more independently from educators. Yuen et al (2011) claims that AR applications are more likely to lead to certain benefits, such as increased motivation and higher students' engagement in learning. Marc et al (2016) believes that AR leads the learners to better retention of words and improves students' attention and satisfaction. Similarly, Chen and Chan (2019) believe that there might be some challenges associated in using AR flascards in young learners' class. However, the learners enjoyed the AR learning activities and they could engage with real world in real time.

\section{METHOD}

Quantitative method was used in this study. It is one in which the investigatory primarily uses post positive claims for developing knowledge (i.e., cause and effect thinking, reduction to specific variables and hypotheses and questions, use of measurement and observation, and test), 
employs strategies of inquiry such as experiments and surveys, and collect data on predetermined instruments that yield statistics data (Cresswell, 2017:21). Moreover, the researcher used Quasi-experimental design. The first step, students were given pre-test (Q1); the second step, the implementation of the treatment (X); and the final step, Post-test was distributed to the students. This study focuses on giving treatment to experimental class by applying Augmented Reality (AR) in teaching English vocabulary. The population of this research was 30 students at second grade of public Elementary school in Padalarang, Bandung Barat. The sample was students of class IIa as an experimental class and class IIb as a control class.

\section{RESULTS AND DISCUSSION}

\section{Results}

This present study used two classes as samples of the research. The first class was experimental class taught using AR and the second called as control class taught using conventional flashcards. Before giving treatments, both classes were given pre-test. The vocabulary test was in the form of multiple choices, fill in the gap and matching.

Table 1. Descriptive Statistic

\begin{tabular}{lllllll}
\hline Score & Class & N & Min & Max & Mean & $\begin{array}{l}\text { Standard } \\
\text { Deviation }\end{array}$ \\
\hline Pretest & Experimental Class & 30 & 10 & 95 & 52.33 & 20.203 \\
\cline { 2 - 7 } & Control Class & 30 & 10 & 95 & 49.83 & 18.406 \\
\hline \multirow{2}{*}{ Posttest } & Experimental Class & 30 & 50 & 100 & 74.83 & 16.108 \\
& Control Class & 30 & 40 & 100 & 62.50 & 14.957 \\
\hline \multirow{2}{*}{ Gain } & Experimental Class & 30 & 5 & 40 & 0.54 & 7.041 \\
& Control Class & 30 & 5 & 35 & 0.28 & 8.976 \\
\hline
\end{tabular}

Based on table 1. Each class consists of 30 students. The result of pre-test can be seen that the minimum score in experimental class and control class are 10. The maximum score for both classes are 95. The mean score of experimental class is 52.33, while in control class is 49.83 . The table above shows the minimum score of posttest in experimental class is 50 , the maximum score is 100 and mean is 74.83 with the standard deviation is 16.108 . Meanwhile, in control class, the minimum score is 40 and maximum score is 100 but the mean is 62.50 and 14.957 for standard deviation. Further, the researcher calculated the normalized gain. The aim of normalized gain is to investigate describing general score improvement of a learning process compared between before and after a method applied. (Hake, 2002: 2).

$$
\text { Normalized Gain }(\mathrm{g})=\frac{\text { Post-test Score }- \text { Pre-test Score }}{\text { Maximum Score }- \text { Pre-test Score }}
$$

Table 2. Categories of Normalized Gain Score

\begin{tabular}{cc}
\hline Normalized Gain Score & Interpretation \\
\hline$-1.00<\mathrm{g}<0.00$ & Decrease \\
\hline $\mathrm{g}=0.00$ & Stable \\
\hline $0.00<\mathrm{g}<0.30$ & Low \\
\hline $0.30<\mathrm{g}<0.70$ & Average \\
\hline $0.70<\mathrm{g}<1.00$ & High
\end{tabular}


Based on the table 2, it can be seen that the gain score of experimental class is 0.54 meaning that there is significance improvement in learning vocabulary. However, in control class, the gain score is 0.28 . It means that the level improvement in this class is low. Normality test was done to measure the distribution of data were normal or not. The measure the data whether or not, it can be seen by comparing the coefficient sig with the probability standard 0.05 if the sig more than 0.05 , it can be concluded that the distribution of data were normal, but if the sig less than 0.05 the data were not normal (Arikunto, 2014). Tabel 3 shows the result of normality test of pretest and posttest of experimental class and control class.

Table 3. Test of Normality

\begin{tabular}{|l|l|l|l|l|l|l|}
\hline \multirow{2}{*}{} & \multicolumn{3}{|c|}{ Kolmogorov-Smirnov $^{\mathrm{a}}$} & \multicolumn{3}{c|}{ Shapiro-Wilk } \\
\cline { 2 - 7 } & Statistic & Df & Sig. & Statistic & df & Sig. \\
\hline Gain Kontrol & .317 & 30 & .000 & .783 & 30 & .000 \\
Gain Eksperimen & .261 & 30 & .000 & .870 & 30 & .002 \\
\hline
\end{tabular}

a. Lilliefors Significance Correction

Based on the table above, the significance of gain score for experimental class was 0.002 and less than 0.05. So, it can be concluded that the data were not normal. Besides, the significance of gain score for control was 0.000 and less than 0.05 . So, it can be concluded the data were not normal. After normality test, the next test that used before non-parametric test was homogeneity test. The result of homogeneity test of gain score in this research can be seen in the table below:

Table 4. Homogeneity of Variance

\begin{tabular}{|l|l|l|l|}
\hline $\begin{array}{l}\text { Levene } \\
\text { Statistic }\end{array}$ & df1 & df2 & Sig. \\
\hline 2.129 & 1 & 58 & .150 \\
\hline
\end{tabular}

Based on the result above, the sig. value is 0.150 . It means that the result of homogeneity of variance is more than 0.05 and it can be concluded that the variances were homogenous.

Table 5. Test Statistic of Mann-Whitney U

Test Statistics ${ }^{\text {a }}$

\begin{tabular}{|l|l|}
\hline & Gain \\
\hline Mann-Whitney U & 74.500 \\
Wilcoxon W & 39.500 \\
Z & 4.142 \\
Asymp. Sig. (2- & 00 \\
tailed) & \\
\hline
\end{tabular}

a. Grouping Variable: Group

The next step was to analyze the data using Mann-Whitney. The result reveals that the AsympSig (2-tailed) is 0.000 . So, the null hypothesis is rejected. Meanwhile, if $\mathrm{p}>\alpha$, it means that Ho 
was accepted. The result in table 5 shows that $p$ value is 0.000 and $\alpha$ is 0.05 . It means that the significance level or probability value (p) was higher than the degree of significance $(\alpha)$. It means that Ho is rejected. In other words, there is a significant difference between students who are taught by using AR and those who are not taught by using conventional flashcards. It can concluded that vocabulary mastery of students in experimental class was more effective using AR than students in control class. In other words, augmented reality (AR) had positive impact in developing students' vocabulary mastery especially for young learners.

\section{Discussion}

From the research findings above, it indicated that the students in experimental class obtained better scores in posttest rather than in control class. Augmented Reality (AR) is a very effective to learn English and it makes lesson more fun for students. According to Yeun et al (2011) AR can be used in an application which is familiar with discovery based learning. A user is provided with information about a real-world place while simultaneously considering the object of interest. Augmented Reality (AR) can be described as one of possible steps between real world and fully virtual reality (Milgram et al, 1994). Into this mixed reality users can make an overlay with virtual objects onto the real world typically by capturing camera images in real-time to produce a new layer to the environment with which they can interact. In the beginning of AR, the use was constrained to head mounted displays and heavy processing units typically placed in backpacks.

With the advancement of technology they have seen an increase of processing power in personal devices which also counts for mobile phones. The introduction of smartphones with greater computing power, hardware for environmental interaction and also fully functional operating systems has allowed implementation of AR in more compact size solutions. With this advancement, AR steps out from researchers laboratories into real world applications and mass market. Further, a research conducted by Santos et al (2016). They found that augmented reality (AR) can improve student attention and satisfaction. Mobile Augmented Reality (MAR) based on Doswell et al (2006) is a term used when equipment through which we achieve AR is small in size and typically easy to carry a smartphone or a tablet. The result of those previous studies are also relevant with the studies conducted by Bedder (2012), Marc C et al (2016), Diegmann et al (2011), and Saffar et al (2016), in which the result of their study showed that AR was effective to improve students' vocabulary mastery.

Based on the experience in implementing AR, the writer got some advantages while using AR media in teaching vocabulary. It could improve learning curve effect. It refers to students who are able to learn faster and easier with AR applications compared to non-AR applications. AR also helped student to be more creative and explorative. Some researchers found that AR could help students to absorb new knowledge and solve problems (Liu, 2019). It promotes the effective environment for conducting collaborative inquiry learning activities (Wang et al, 2012). In addition, the students could interest the process of teaching learning. This students' behavior is also in accordance with Saffar et al (2016) who explained that augmented reality may lead better retention of words and improve students' attention and satisfaction.

\section{CONCLUSION}

There are two major conclusions found. They are (1) there is significant improvement in students' vocabulary mastery for experimental groups after having Augmented Reality (AR) as treatment; (2) there is no significant improvement in learning vocabulary for students who 
learned flashcard (control group). The computation of pre-test score both in control and experiment classes that the data distribution in both of classes was not normality distributed and homogeneity of the data was homogenous. Further, the statistical test hypothesis or comparing two means was used Mann-Whitney $U$ test in order to analyze the significant effect of post-test score, the result showed that the experiment group had significantly different. The result of the calculation showed that Sig.(2-tailed) is 0.000 which was lower than 0.05 . Therefore the null hypothesis was rejected. It means that the treatment which was given to the experimental group significantly improved students' vocabulary mastery.

\section{ACKNOWLEDGMENTS}

Our attention has recently been drawn to the headmaster of school who gave us a chance to conduct the research and the English teachers who helped to implement the AR in class. Secondly, we would also like to thank to those who have indirectly guided and given us unending support.

\section{REFERENCES}

Apsari, Y. (2012). Teaching English vocabulary through songs. Universitas Pendidikan Indonesia.

Arikunto.S. (2014). Prosedur Penelitian Suatu Pendekatan Praktik. Jakarta: Rineka Cipta.

Barcelon, B. (2010). the-life-of-generation-z. Retrieved 09 2018, from teenlife.blogs.pressdemocrat.com: http://teenlife.blogs.pressdemocrat.com/10220/thelife-of-generation-zl

Bedder, P. (2012). LANGUAGE LEARNING VIA AN ANDROID AUGMENTED REALITY SYSTEM. Blekinge Institute of Technology, Computer Science. Sweden: Thesis No: MCS-2012:20.

Brown, H. (2001). Language Assesment. Principal An Interactive Approach to Language Pedagogy. San Fransisco: Long Man.

Chen, R. W and Chan, K.K. (2019). Using Augmented Reality Flashcards to Learn Vocabulary in Early Childhood Education. Journal of Educational Computing Research 0(0) 1-20. Retrieved 18 January from: https://www.researchgate.net/profile/Kan_Kan_Chan/publication/334004116_Using_A ugmented_Reality_Flashcards_to_Learn_Vocabulary_in_Early_Childhood_Education/1 inks/5d7a6235299bf1ec8bd35716/Using-Augmented-Reality-Flashcards-to-LearnVocabulary-in-Early-Childhood-Education.pdf

Cresswell, J. W. (2012). Educational research : Planning, conducting and evaluating quantitative research. Boston: Person Education, Inc.

Diegmann, Phil \& Schmidt-Kraepelin, Manuel \& Eynden, Sven \& Basten, Dirk. (2015). Benefits of Augmented Reality in Educational Environments - A Systematic Literature Review.

Doswell, J. T., Blake, M. B., \& Green, J. B. (2006, December 19). Mobile Augmented Reality System Architecture for Ubiquitous E-Learning. Fourth IEEE International Workshop on Wireless, Mobile and Ubiquitous Technology in Education (WMTE'06). USA: IEEE.

Kamarainen, A. M., Metcalf, S., Grotzer, T., Browne, A., Mazzuca, D., Tutwiler, A. S., et al. (2013). EcoMOBILE: Integrating augmented reality and probeware with environmental education field trips. Computers and Education, 68, 545-556.

Liu, T.- Y. (2009). A context- aware ubiquitous learning environment for language listening and speaking. Journal of Computer Assisted Learning, 25, 515-527. 
Liu, T.-Y., Tan, T.-H., \& Chu, Y.-L. (2009). Outdoor Natural Science Learning with an RFIDSupported Immersive Ubiquitous Learning Environment. Journal of Educational Technology \& Society, 12(4), 161-175.

Milgram, P., \& Kishino, F. (1994). A Taxonomy of Mixed Reality Visual Displays. IEICE TRANSACTIONS on Information and Systems, E77-D, 1321-1329.

Nurdiansyah, D. M. R., Asyid, S. A., \& Parmawati, A. (2019). Using Color Coding To Improve Students'english Vocabulary Ability. Project (Professional Journal Of English Education), 2(3), 358-363.

Paul, D. (2003). Teaching English to Children in Asia. Hong Kong: Pearson Longman Asia Ltd.

Pinter, A. (2006). Teaching young language learners. Oxford: Oxford University Press.

Reilly, P. (2012). Understanding and Teaching Generation Y. English Teaching Forum, 50, 2 11.

Sadikin, I. S. (2012). Young Learners' Vocabulary Improvement through Audiovisual by Using YouTube Videos. A Research Paper (Thesis). English Department of Indonesia University of Education (UPI) Bandung.

Santos, Marc Ericson \& Lübke, Arno \& Taketomi, Takafumi \& Yamamoto, Goshiro \& Rodrigo, Ma \& Sandor, Christian \& Kato, Hirokazu. (2016). Augmented reality as multimedia: The case for situated vocabulary learning. Research and Practice in Technology Enhanced Learning. 11. 1-23. 10.1186/s41039-016-0028-2.

Saffar, A. H., Al-Jafar, A. A., \& Yousefi, Z. H. (2016). The Effectiveness of Using Augmented Reality Apps in Teaching the English Alphabet to Kindergarten Children: A Case Study in the State of Kuwait. EURASIA Journal of Mathematics Science and Technology Education, 13(2), 417-440.

Vate-U-Lan, P. (2012). An Augmented Reality 3D Pop-Up Book: The Development of a Multimedia Project for English Language Teaching. IEEE International Conference on Multimedia and Expo. Melbourne, VIC, Australia: IEEE.

Wang, H.-Y., Lin, T.-J., Tsai, C.-C., Duh, H. B.-L., \& Liang, J.-C. (2012). An Investigation of Students' Sequential Learning Behavioral Patterns in Mobile CSCL Learning Systems. IEEE 12th International Conference on Advanced Learning Technologies (pp. 53-57). Rome, Italy: IEEE.

Yuen, S. C.-Y., Yaoyuneyong, G., \& Johnson, E. (2011). Augmented Reality: An Overview and Five Directions for AR in Education. Journal of Educational Technology Development and Exchange, 4(1), 119-140. 